\title{
Local "Battlegrounds". Relocating Multi-Level and Multi-Actor Governance of Immigration
}

\author{
Iraklis Dimitriadis ${ }^{1}$, Minke H. J. Hajer ${ }^{2}$, Elena \\ Fontanari ${ }^{3}$ and Maurizio Ambrosini ${ }^{4}$
}

\begin{abstract}
Migration to Europe is a complex social process that European governments seek to govern at international, European, national and local levels. Studies on the politics and governance of migration have frequently used the multi-level governance (MLG) approach in order to understand the process of immigration policymaking regarding admission and reception, diversity management, and integration of immigrants (Zapata-Barrero et al., 2017). Recent research has delved into the dynamics and the emergence of different MLG arrangements in order to analyse the complex relations among different scales of governance within states. This research sheds light on the various levels of MLG - local, regional, national, European, or even global - which is the vertical dimension. However, this literature does not effectively explore the relations among different kinds of both public and private actors (Campomori and Caponio, 2017), which is also referred to as the horizontal dimension of MLG (Campomori and Ambrosini, 2020). In other words, the MLG approach may be considered too descriptive to grasp the conflictual nature of interactions among different actors (but see, among the exceptions, Spencer, 2018). The relations among actors may be harmonious, but also contentious, they may involve collaboration, but also conflict. Besides being criticized for providing scant insights into the networks of different actors and the nature of their connections, the MLG approach has been criticized for placing too much emphasis on the outcomes of governance processes, thereby neglecting those processes that produce them (Caponio and Jones-Correa, 2018; Pettrachin, 2020). In recent years, however, the MLG
\end{abstract}

\footnotetext{
1 Postdoctoral Fellow, Department of Social and Political Sciences, Università degli Studi di Milano, Via Passione 13, 20122 Milano; iraklis.dimitriadis@unimi.it

2 Postdoctoral Fellow, Department of Social and Political Sciences, Università degli Studi di Milano, Via Passione 13, 20122 Milano; minke.hajer@unimi.it

3 Postdoctoral Fellow, Department of Social and Political Sciences, Università degli Studi di Milano Via Passione 13, 20122 Milano; elena.fontanari@unimi.it

4 Full Professor of Sociology, Department of Social and Political Sciences, Università degli Studi di Milano, Via Passione 13, 20122 Milano; maurizio.ambrosini@unimi.it This article is related to the PRIN 2017 research project ASIT (Italian Ministry of University and Research. ASIT project - PRIN - Research, prot. 2017999JXZ).
} 
approach has evolved, becoming more nuanced. For instance, some scholars suggest that, rather than seeing MLG as one fixed perspective, it should be considered as one of many types of governance in multi-level settings (Scholten et al., 2018), or, similarly, as one of many "instances of multilevel politics, each defined by a particular configuration of actors, scale and decision-making process" (Alcantara et al., 2016: 46).

Moving beyond the MLG approach, this literature review focuses on studies regarding the local level in immigration governance. It considers local policies and administrative practices on the one hand, and the role of multiple civil society actors engaged in the reception of asylum seekers on the other. Reflecting on various studies conducted in Europe and, occasionally, in the USA, it seeks to reconstruct the multiplicity and heterogeneity of the governmental and non-governmental actors engaged in the management of migration, and aims to identify possible gaps in this literature. Moreover, given the European context of growing politicization of migration, and of increased polarization regarding migration within local communities, this article offers an analytical literature review of studies that deal with the dynamics between local authorities and the local civil society. Migration scholars have highlighted how the local level can be the basis for exclusionary policies (Semprebon, 2011; Ambrosini, 2013 and 2018), as well as intolerant policies towards migrants, by installing new mechanisms of control in everyday spaces (Gilbert, 2009; Lebuhn, 2013; Gargiulo, 2017). However, local authorities have also undertaken initiatives of immigrant inclusion, thereby creating cities in favour of refugees' arrival (Bauder, 2017; Garcés-Mascareñas and Gebhardt, 2020; Irgil, 2016; Oomen, 2020a; Oomen and Leenders, 2020). Research on grass-roots initiatives has highlighted the role of local actors in supporting migrants and refugees politically (Bazurli, 2019; Chtouris and Miller, 2017; Karakayali and Kleist, 2016; Mayer, 2018; Raimondi, 2019; Youkhana and Sutter, 2017; Zamponi, 2017), as well as improving their integration (Alexander, 2007). However, local actors have also mobilized in order to stop refugees' reception or to hinder initiatives in favour of immigrant integration (Castelli Gattinara, 2017; Fouskas, 2019). Finally, this review also considers the role of migrants themselves (Ataç et al., 2016; Fontanari, 2018; Ikizoglu Erensu, 2016).

Our analysis of the literature confirms this increasing importance of local policies, or the local turn in governance (Glick-Schiller and Caglar, 2009; Campomori and Caponio, 2017; Glorius and Doomernik, 2020; Zapata-Barrero et al., 2017), as well as the significant role of different non-governmental actors in migration and asylum governance (Ambrosini, 2018; Campomori and Ambrosini, 2020; Garkisch, et al., 2017; Spencer, 2018). Even though some scholars grasp the dynamic interactions among actors and how they influence policy outcomes, we maintain that more emphasis should be given to how the horizontal dimension of MLG shapes migration governance. We therefore call for further analysis of the dynamics and complex relations not only among different scales (i.e. the vertical dimension), but also among public and private actors. Moreover, we consider local policies to be the result of conflict and cooperation, alternative views and political actions, official policies and practical help, formal statements and informal practices. We do so rather than seeing the relations among different actors as the result of a "negotiated order."These dimensions are encapsulated in the concept of "battleground" (Ambrosini, 2018 and 2020; Campomori and 
Ambrosini, 2020), an analytical notion with which the management of asylum and migration can be understood.

\section{Bordering Practices within Local Communities}

Critical border studies stress the proliferation of borders within countries. They highlight how contemporary capitalism produces not only physical and legal barriers among states, but also administrative borders within countries that select among their populations. The production of local borders should be framed within wider global processes affecting several spheres of contemporary social life. It may be said that the real function of borders is this differential regulation. Borders, seen as dynamic processes rather than as fixed and material entities, function as "filters" of access to both territories and resources (Mezzadra and Neilson, 2013; Kolossov and Scott, 2013; Bonizzoni, 2020). Accordingly, a global stratification system is produced where the mobility of some people - like migrants and refugees - is considered undesirable or socially threatening and is therefore restricted. Some authors talk about the creation of an "im/ mobility regime" (Glick-Schiller and Salazar, 2013). Freedom of movement thus becomes a scarce resource. Here nation-states emerge as the main actors in "the monopolization of the legitimate means of movement" (Torpey, 2000). They do so through a global system of passports and visas regulating access to national territories. In other words, contemporary migration policies grow increasingly selective (de Haas et al., 2016; Ambrosini et al., 2020). "Bordering practices" should be understood as the processes of classifying and ordering space. In this way, the border is used as a governing technique (Green, 2013).

In border studies, the various devices and techniques used to manage the mobility of migrants have mostly been analysed with reference to Foucauldian theory (Walters, 2015). Some border practices and devices produce forms of containment (Tazzioli, 2018) and confinement (Picker and Vivaldi, 2019; Rahola, 2010) intended to sort, rank, and block some categories of people on the move. A typical governmental technique is the organisation of these people into categories - such as "economic migrants", "asylum-seekers", "refugees", "illegal migrants", etc. - and the creation of hierarchies among them according to their legal statuses (Anderson, 2012; De Genova, 2013; Green, 2013; Isin and Turner, 2002; Rigo, 2011). Legal status emerges as a crucial governmental tool with which to selectively restrict access to several rights and social benefits within European societies and produce inequalities (Faist, 2013). Indeed, at the beginning of the 2000s, some research stressed the creation of a "gradual system of rights" (Ong, 2006) entailing a "civic stratification" (Morris, 2003), that is, a hierarchy of access to rights and welfare benefits determined by legal status. This reflects competition among various structural constraints, such as welfare resources, labour market management, and international obligations like human rights conventions.

The production of borders is also apparent in other practices of local administrations. Empirical studies have shown how various actors create local borders by implementing restrictive policies directed at migrants and refugees. The notion of "local policies of exclusion" (Ambrosini, 2013) has highlighted the "institutional obstacles" to the rights of minorities and their freedom to express their cultural 
and religious identity. Local municipalities emerge as actors that either implement European and national policies in a restrictive way or even invent regulations against migrants on their own initiative. They can thereby prevent refugees and migrants from integrating into the social structures of the arrival societies. In particular, it has been shown how several mayors have deployed municipal ordinances as means to restrict migrants' and refugees' access to various (social) rights. These administrative measures have sometimes been implemented in contrast to national laws in the name of emergency or urban security. Another example evidences how mayors, by obstructing the registration of migrants or refugees with the Registry Office (to obtain legal domicile), can directly block their access to healthcare, political rights (eligibility to vote in local elections), welfare benefits, and access to school for children (Bonizzoni, 2020; Campomori and Ambrosini, 2020; Gargiulo, 2012; Gjergji, 2016; Marchetti, 2020). Other studies have highlighted how local authorities have obstructed access to housing and social rights through the implementation of restrictive administrative practices (Bolzoni et al., 2015). Moreover, the lack of adequate policies for the reception of asylum seekers or transit migrants in Italy has resulted in the exclusion of some people from social services, based on politically constructed categories of inclusion or exclusion (Semprebon and Pelacani, 2020). These studies unveil tensions at work within the MLG of asylum and immigration. They show how the restrictive local implementation of national laws can create gaps between the legal provision and the effective exercise of social rights.

Research has likewise shown how welfare policies can be used as instruments for border control and management of human mobility. Local bureaucratic offices can produce hierarchies and stratification in the access to rights and welfare benefits by implementing restrictive national welfare policies and creating regulations hostile to migrants (Lafleur and Mescoli, 2018). Indeed, migration control practices are embedded in ordinary legal frameworks and are created by means of ordinary border politics (Basaran, 2008; Tuastad, 2017). National bureaucracies operate within a legal framework through an excess of administrative rules that have become progressively institutionalised. The management of migrants and refugees exhibits a trend of slow erosion of existing legal standards by local bureaucracies (Campesi, 2014). Although refugees are entitled to a series of rights and benefits in host countries, the local implementation of these rights shows discrepancies between legal provisions and the effective exercise of rights, as well as new restrictive measures introduced by local actors.

In what follows, we describe the increasingly active role of the horizontal dimension of migration governance. We show how semi-public institutions and private actors have gained importance in the management of immigration in general. This also means that these non-state actors play a role in the construction of borders at the local level. By monitoring migrants and refugees through their legal status, many local institutions - welfare agencies, municipal administrations, universities, public and private schools, health care providers, doctors, hospitals, housing agencies, banks and insurance companies - govern the everyday lives of refugees and migrants. Such local state agencies and private service providers systematically check residents' identification papers, and through these interactions local borders are produced (Lebuhn, 2013). They thus perform their own role in the process of local bordering. 


\section{At the Border: Local Conflicts in Border Places}

Migration policies and control measures deployed in Europe in recent years, and particularly after the "long summer of migration" of 2015 (Hess et al., 2017), have the tendency to block the intra-European mobility of asylumseekers and refugees. Since 2011, in conjunction with the Arab Spring uprisings and the Libyan war, the European system of managing migration across the Mediterranean Sea has partially broken down and new processes of bordering have been deployed. Several empirical studies have shown how the bordercrossing mobility of refugees within Europe has emerged from the tension between restrictive policies of migration control and the everyday struggles of refugees and their supporters around the political ideal of freedom of movement (Agier, 2014; Christodolou et al., 2016; Denaro, 2016; Fontanari, 2018; Mainwaring; 2016; Mezzadra, 2020; Picozza, 2017; Schmoll et al., 2015). However, only during the long summer of migration of 2015 did the border-crossing mobility of refugees and the related breakdown of the Dublin Regulation reach a peak in the public debate (Kasparek, 2016), strongly influencing the subsequent migration policies at the European and national levels.

In the years 2016 and 2017, several policies and measures marked a process of re-bordering Europe. The strengthening of borders within Europe and countries is a new feature of policies and practices in migration management. This is despite the focus on the EU's external borders that persists through the multiplication of bilateral agreements with third countries (Cassarino, 2016) - such as the EU-Turkey readmission agreement of 2016 and the Italy-Libya bilateral agreement of 2017. Indeed, the EU's internal borders have been reintroduced through the enforcement of border controls in transit places between countries. For instance, research on border locations such as Calais at the France-UK border (Agier et al., 2018), Brenner at the Italian-Austrian border (Weissensteiner, 2015), Ventimiglia and Roja Valley at the Italian-French border (Giliberti and Queirolo Palmas, 2020) and Como-Chiasso at the Italian-Swiss border (Tazzioli, 2018) has stressed these new bordering mechanisms. There is an empirical evidence suggesting that pro-migrant actors may be engaged in "debordering solidarity" against policies of exclusion (Ambrosini, 2018 and 2021). However, other actors opposing migration (parties, movements) also assume a role on the local "battleground". They contribute to bordering practices, or they mobilize to block pro-migrant local policies. Moreover, the local "battleground" shows the involvement of a variety of civil society actors in migration governance - NGOs, churches, political parties, volunteers, social movements and mobilizations of citizens both in favour of and against migrants and refugees. The production of borders is a process evident in very visible and formal border locations. It also takes place within urban spaces through national and local policies, and through less visible and more indirect practices (i.e. within the field of local administration).

\section{Inclusion Policies at the Local Level}

Despite the focus of migration scholars on how local authorities engage in bordering practices, several studies have suggested that local governments promote initiatives and policies that favour the integration of immigrants (Marrow, 2012; van der Leun and Bouter, 2015; Oomen, 2020b). 
According to the MLG approach, these policies usually involve coordination across different levels of governance, and harmonious relationships may result in more effective policies. However, Scholten (2015) has raised doubts regarding the interplay between local and national governments, and argued for a "decoupling" of their interactions. "Decoupled" relations are the result of different sets of interests and goals across tiers of governance. Similarly, the "local turn" in immigration (Glick-Schiller and Caglar, 2009) indicates that policies at the city level may diverge from, or compete with, national governments' agendas in the field of migration governance.

While the "decoupling" of local migration policies has been evident in the USA since the 1980s (Oomen, 2020a), it has only become apparent in the European context since 2015. In regard to refugees and (irregular) migrants, this trend has been closely examined in the recent scientific debate on "Cities of Refuge" (Oomen, 2020a; 2020b; Oomen and Leenders, 2020; Garcés-Mascareñas and Gebhardt, 2020), or in the American literature on "Sanctuary Cities" (Ridgley, 2008; Hintjens and Pouri, 2014; Bauder, 2017). This literature has stressed the sometimes problematic relations among local and national actors, civil society, and migrants and refugees themselves. The debate sheds light on how some cities have responded to the inadequacy of national migration and asylum laws and policies. In these cities, local governments have developed an independent stance, promoting integration and inclusion, whilst the national state remains undecided or hostile to migration. These cities warmly welcome new arrivals and are proactive in promoting their own agendas by implementing (political) initiatives in favour of human and migrant rights. Their mayors and municipal councils devise measures to break down existing borders, which are discussed, coordinated or disseminated within city networks (Oomen, 2020b). In Cities of Refuge, Oomen (2020a) suggests that the actions of local authorities concern different components of citizenship. Cities' initiatives can shape legal status and political membership, set out rights and obligations, stimulate civic virtues and practices of engagement, as well as strengthen discourses of inclusion and participation. Kos and colleagues (2016), for instance, explored how Dutch municipalities developed practices to cope with exclusionary national asylum policies. Because substantial numbers of asylum seekers were failing to obtain regular status, local governments collaborated with NGOs to operate emergency reception and accommodation facilities. This created tension between themselves and national actors.

The expression "cities of refuge" also denotes a "culture of welcome": that is, "a historically transmitted pattern of meaning, embodied in symbols, a system of inherited conceptions expressed in symbolic forms" (Oomen, 2020a: 129). The British City of Sanctuary movement, for example, promotes this culture of welcome towards asylum-seekers and refugees through various forms of practical assistance: material support and legal advice provided by communitybased initiatives to help forced migrants. These practices contest bordering processes, and they provoke disputes on "rightful presence" (Squire and Darling, 2013) and broader questions of justice. But this contrasts with the idea of "levelling" the hierarchies among different government actors proposed by the MLG approach, because "there are a number of areas in relation to the reception of newcomers over which local authorities do have direct control and which continue to act as a focal point for targeted interventions by local authorities" (Broadhead, 2020: 3). 
Another example is provided by Garcés-Mascareñas and Gebhardt (2020), who describe the innovative local policies promoted by the local government of Barcelona. This city responded to the needs of new arrivals in a context in which the national government was reluctant to share responsibilities with lower tiers of government. Barcelona's mayor called the city an "open city" or a "City of Refuge" in early September 2015, and fifty-five other Spanish city councils followed his example a week later. They created a network of cities in order to better coordinate the provision of services to refugees. Moreover, these cities also shifted their advocacy to the supranational level so as to circumvent national governments; a form of "venue shopping" (Guiraudon, 2000) in order to remedy failures of national policies. It can be argued that "Cities of Refuge" do not only provide help and solutions to vulnerable people; they also contribute to the consolidation of human rights globally, as well as to the effectiveness of actions at the local level (Oomen, 2020b). In other words, they have a symbolic purpose because they strengthen the welcoming of migrants and refugees, and the legitimacy of local policies. In regard to this last point, Caponio (2018) highlights how in Italy the participants in a network of welcoming cities have sought to decouple local policies from national dynamics and to strengthen the legitimacy of local initiatives. They have done so by "showcasing" (e.g. organization of events to communicate the issue of local identity cards); "storytelling" (e.g. promotion of alternative narratives on migration, such as emphasising a city's historical links with diversity); and "shaming" (e.g. speeches by local politicians denouncing anti-immigrant policies or frames such as "Fortress Europe"). But a critical issue still persists: this symbolic support often prevails over the practical support guaranteeing a better reception of people in need of international protection.

While the examples presented above furnish profound insights into the process of de-bordering by local authorities, it should be borne in mind that other actors at the local level can also oppose restrictive policies. According to the street-level bureaucracy approach (Lipsky, 1980), an in-depth understanding of migration management in arrival societies should also consider the possibilities to negotiate borders embedded in the power relations among migrants and refugees, bureaucratic officials, and other civil society actors (Ellerman, 2006). In this regard, Price and Spencer (2014) argue that bureaucrats have the discretionary power to favourably decide on migrants' access to welfare benefits on the basis of "deservingness". The extent of this power varies among cities and depends on their size because civil servants' preferences can play a crucial role in small and medium-sized towns (Oomen and Leenders, 2020). A recent study by Zimmermann and colleagues (2020), for instance, shows that the interaction between non-governmental organisations and the public administration can meet the security needs of refugee women in Germany.

\section{Civil Society: Taking Over the State's Responsibilities, and Going Beyond}

Governments and civil society actors have a complex relationship when it comes to the welcoming of migrants and refugees. Scholars have argued that during, and after, the 2015 "long summer of migration" (Hess et al., 2017), state systems failed to adequately handle the increasing numbers of migrants arriving 
in European countries (Simsa, 2017). Moreover, asylum and migration policies were driven by an "organized non-responsibility", by which is meant that EU member states passed responsibilities to each other (Pries, 2018; Vandevoordt, 2019a). In this context, civil society organizations (CSOs), and hence the horizontal dimension of MLG, played an important role in the governance of new arrivals, i.e. in the reception of asylum seekers (Haselbacher, 2019). This can be interpreted as a shift of responsibilities, not only from the national level to the local level, but also from the public sector to the private sector (Caponio and Jones-Correa, 2018). This was due to two factors: the gap left by national governments in regard to the reception of asylum seekers, and initiatives to support migrants undertaken by civil society actors, often against the political will of governments.

Civil society organizations can be broadly defined as all formal and informal social institutions between the state, the economy and the private sphere (Odmalm, 2004; Putnam, 1993; Simsa, 2017: 78-79). A variety of civil society actors are involved in the reception and integration of migrants: non-governmental organizations (NGOs); non-profit organizations (NPOs) as well as grassroots initiatives (Simsa, 2017; Togral Koca, 2019; Tsavdaroglou et al., 2019); volunteers spontaneously mobilized in informal ways (Ambrosini, 2019); and refugees themselves (Hinger et al., 2016; Belloni 2016; Raimondi, 2019; Ponzo and Pogliano, 2019). These civil society actors all play their part in the reception of asylum seekers. Especially NGOs have become key players in the organization of migrant reception, and the provision of basic care (Haselbacher, 2019; Pries, 2018). Grassroots initiatives by ordinary citizens welcome migrants at train stations (Boersma et al., 2019; Sinatti 2019), donate food and clothes (Zamponi, 2017), or organize language classes (Hamann \& Karakayali, 2016). Activists and social movements also provide services to migrants (Belloni, 2016; Raimondi, 2019).

Civil society actors have historically played a role in giving assistance to groups marginalized because of their nationality or religion, also when working against public policies. Examples are the provision of services to migrants in France with false ID documents by the private association "Service Social d'Aide aux Migrants" (Social service of assistance to migrants) during the interwar period (Chibrac, 2004); or the solidarity and help given to the Jewish population in "one thousand and one ways" by French citizens (Semelin, 2019: 273). Asylumseeker reception, therefore, is not a new development. However, during the post-2015 period the role of citizens and private associations was extended and adapted substantially (Larruina et al., 2019) to also include tasks that traditionally pertained to the state. Voluntary organizations and initiatives proved able to respond more rapidly and more adequately to changing local needs, while governmental actors and some larger and more institutionalized NGOs were held back by their "limited resources and unclear policies" (De Jong and Ataç, 2017: 28). Governmental action (or inaction) in the field of migration can be characterized as a form of emergency governance, rather than coherent and strategic governance (Panizzon and van Riemsdijk, 2019; Simsa, 2017).

CSOs have been principally engaged in medical care, social assistance, language classes, housing, and social integration. Firstly, NGOs have become the primary healthcare providers for immigrants outside reception centres, and 
voluntary work by healthcare professionals has become a key non-monetary input to the organization of healthcare services for immigrants (Ambrosini, 2015; Bozorgmehr et al., 2019). Secondly, volunteers have engaged in the provision of social assistance to migrants. Bonizzoni (2019), for example, describes how in Italy the "Zampa Law" introduced the figure of the "volunteering guardian", a volunteer that legally represents and safeguards the interests of unaccompanied minors on Italian territory. Previously, it was under the responsibility of the municipality, the mayor and social workers. However, the use of volunteers has been considered a way to protect unaccompanied minors more efficiently. Moreover, Schweitzer (2019) highlights how NGOs in Barcelona and London play a significant role in arranging access to (public) services for irregular immigrants. They are often formally entitled to these services but need assistance with the bureaucratic procedures. Thirdly, refugee housing is usually a responsibility of the state. However, during the large influx of migrants, states relied on collaboration with civil society to organize housing for refugees. Hinger and Schaefer (2019) describe the case of decentralized housing plans in Leipzig and Osnabrück (Germany) which included church organizations (Caritas, the Johanniter, Malteser), NGOs (Red Cross, Outlaw), as well as the army and private security companies. Moreover, squatting and informal settlement have become key ways in which immigrants can live outside formal reception centres while being excluded (formally or informally) from the housing market. Social movements, squatters' movements and activists play a crucial role in these squats and camps (Belloni, 2016; Grazioli, 2017; Raimondi, 2019; Sandri, 2018; Ponzo and Pogliano, 2019).

Fourthly, besides the more basic provision of help, civil society actors assist the integration of migrants into receiving societies in various ways. For example, NGOs, as well as social movements and grassroots initiatives, organize language classes (Hamann and Karakayali, 2016; Hoppe-Seyler, 2020). Or grassroots initiatives organize meetings between citizens and migrants in neighbourhoods (Agustin and Jorgensen, 2019). NGOs can also be seen as part of the official process of helping migrants with formal integration programmes, as in the case of the Dutch Refugee Council (Van Heelsum, 2017: 2143). Moreover, helping migrants to participate politically and claim their rights can be seen as a part of the integration process (Nicholls, 2013a; Nordling et al., 2017; Sandri, 2018; Sinatti, 2019; Vandevoordt, 2019b).

Analysis of civil society responses to asylum governance in the post-2015 period shows that those years saw an impressive rise in grassroots citizen initiatives. These groups started to organize and played a distinct role in the reception of asylum seekers, alongside the organizations already created and committed to the cause of refugee reception. This period is also referred to as the "summer of welcome" or "welcome culture" (Fleischmann, 2017; Fleischmann and Steinhilper, 2017; Hamann and Karakayali, 2016). These authors describe a variety of loosely institutionalized and self-organized initiatives consisting of volunteers who often had not previously been concerned with refugees. They also describe groups traditionally committed to the cause of refugees like the radical left, antiracist, and religious groups. These grassroots initiatives, like other forms of pro-migrant volunteering, can be a response to right-wing anti-migrant sentiments and discourses in society (Hamann and Karakayali, 2016). They can also be seen as a way to express frustration with the government's approach to 
asylum seeker reception (Togral Koca, 2016). However, at the same time those helping migrants often tend to frame this help in explicitly apolitical terms, as a purely humanitarian act (Fleischmann and Steinhilper, 2017; Sinatti, 2019; Parsanoglou, 2020; Schwiertz and Schwenken, 2020). Consequently, scholars have questioned whether or not these forms of help should be interpreted as forms of political action. Indeed, due to the involvement of volunteer groups previously uninvolved with migrant issues, help to migrants is no longer solely a cause pursued by religious charities or political activists. As the help to migrants has become more mainstream, the newly involved citizens have often avoided explicit political contextualization (Fleischmann and Steinhilper, 2017).

Conversely, traditional political actors, like social movements and activist networks, also shift their activities towards help for migrants (Della Porta, 2018). Belloni (2016), for example, describes how migrant squats become places for forms of "welfare from below" because squats provide shelter as well as forms of social security (Belloni, 2016). Zamponi (2017: 97) calls this a trend of "direct social action", which he defines as comprising "actions that do not primarily focus upon claiming something from the state or other power-holders but that instead focus upon directly transforming some specific aspects of society by means of the action itself". Similarly, Sandri (2018) uses the expression "volunteer humanitarianism" to denote the connection between humanitarianism and open forms of protest against institutional border securitization practices.

It should be added, however, that civil society and humanitarian actions have also been criticised, not only by political parties and citizens against immigration (Castelli Gattinara, 2017) but also by scholars who have cited unintended consequences and limitations of humanitarianism. Some critics, for instance, refer to practices that tend to silence, infantilize, victimize refugees, and de-historicize or de-politicize their condition (Malkki, 1996; Rajaram, 2002; Khosravi, 2010; Ticktin, 2014).

In sum, there is a myriad of formal and informal ways in which civil society organizations can be seen as part of the reception process of migrants and refugees. However, what is often lacking in terms of the MLG approach is analysis of the interaction between these non-governmental actors and governmental actors. Or consideration is not made of whether and how the former can challenge policies decided at a higher level of governance or determine outcomes in terms of immigration governance (Marzorati et al., 2017).

\section{Negative Attitudes Towards Immigrants and Asylum Seekers}

One observation regarding the literature on civil society responses to the large influx of migrants since 2015 is that it tends to focus on the "positive" responses to migrants and on the ways in which civil society helps migrants. But civil society actors can also oppose migration and may challenge governance in this way. Welcoming initiatives whereby a broad alliance of civil society actors provide help and promote tolerance take place in contexts where public opinion often expresses resentment towards asylum seekers (Haselbacher and Rosenberger, 2018). Anti-migrant mobilisations have been described in terms of 
an interweaving between the rise of European right-wing groups and far-right activism. This can be observed both in terms of on-the-ground mobilizations and protests (Castelli Gattinara, 2017; Rucht, 2018; Fouskas, 2019) and as a digital phenomenon (Ekman, 2018; Kopytowska et al., 2017). Nevertheless, the literature remains largely silent on these negative civil society attitudes towards migrants. It has done so even though not all civil society actors have responded positively to migrants. Labour unions (in Northern Europe), for instance, have been faced with the dilemma of whether they can support the interests of migrant-workers and native-workers at the same time (Marino et al., 2017), given that the latter fear competition by the former. Moreover, some religious actors have expressed anti-migrant sentiments. Narkowicz (2018) describes a highly divided Catholic Church in Poland, where the general stance of the Catholic Church of welcoming refugees contrasts with strong anti-migrant sentiments, and Islamophobia in Polish "right-wing Catholicism". A similar case is described in Norway, where at the beginning of the "refugee crisis" churches played an active role in the reception of refugees but over time were increasingly confronted with a fear of the faith of others. This concerned the anxiety of sections of the Norwegian population that the influx of mostly Muslim migrants into an increasingly secularizing country, as well as a new plurality of faiths, would undermine social and political cohesion (Stålsett, 2018: 113-114). Likewise, in Italy, the relation between politics and civil society has often been characterised by conflict. Mobilizations from below, local authorities and right-wing movements have acted to prevent the establishment and functioning of reception centres (Ambrosini, 2018; Campomori and Ambrosini, 2020), and they have campaigned for the closure of squats occupied by asylum-seekers (Ponzo and Pogliano, 2019).

\section{The Role of Migrants and Refugees}

In regard to the role of non-state actors in influencing the MLG of migration, some empirical results suggest that migrant and refugees themselves may also be involved (Hinger et al., 2016; Fontanari, 2018; Fontanari and Ambrosini, 2018; Parsanoglou, 2020). Hinger and colleagues (2016: 51), for instance, argue that coalitions between asylum-seekers and support groups influenced accommodation practices and decisions in German municipalities. Moreover, numerous cases have been described of attempts by social movements of refugees and/or undocumented migrants throughout Europe to influence policy-making and improve their situation (e.g. Ataç et al., 2016; Cappiali, 2016; Chimienti, 2011; Monforte and Dufour, 2011; Raimondi, 2019; Frazzetta and Piazza, 2020). Bazurli (2019), for example, describes how social movements by and for migrants specifically seek to influence the city-governments of Milan and Barcelona on how those local governments handle the arrival and transit of migrants. Similar research conducted in Italy suggests that migrants and refugees in collaboration with native citizens can use squatting to address and find solutions for the housing problems of these populations (Belloni, 2016; Grazioli, 2017). Generally, empirical research around the world (Nyers and Rygiel, 2012; Marciniak and Tyler, 2014) has highlighted the active role of migrants and refugees in protesting against restrictive mobility regimes and the security measures deployed to block them. Some of these actions have been understood as deliberate political practices or part of organised political protests, while others have been understood as forms of everyday resistance 
(Scott, 1985; Fontanari and Ambrosini, 2018; Chacko and Price, 2020). Finally, the analysis of MLG should take account of struggles for citizenship from below and struggles for the recognition of human rights by the persons directly affected by restrictive migration policies. Migrants and refugees often interact with civil society support groups, as well as with border controllers and policy-makers. By doing so, they contribute to the conflictual and dynamic process that we call the "battleground" of migration governance. By contrast, Nicholls (2013b) has highlighted the tensions that may arise between migrants and advocacy groups because native activists speak on behalf of migrants, setting aside the voice and will of the latter. Overall, it can be argued that the literature often fails to grasp the links and interplay between the action of migrants and refugees themselves and civil society, and how they can shape immigration governance.

\section{Conclusion. The Battleground of Asylum Policies}

Having considered a range of case studies on the engagement of local actors in migration and asylum governance, we state that more emphasis should be given to the horizontal dimension and the conflictual relations among different actors at the local level; rather than only considering the vertical cooperation and coordination among actors. The relationship between public and non-public actors within the levels of government, and how these interactions influence or shape policies in relation to migration governance, is an addition to the "traditional" MLG approach. The actual governance of migrants and asylum may be seen as the product of conflicting processes in which different local actors (pro- and anti-immigrant organizations/groups and the immigrant organizations themselves) have a crucial role. Special attention should be paid to contradictions and conflicts among actors of different kinds. This is because of the increasingly significant engagement of actors in favour of migration and the emergence of "cities of refuge" (Oomen, 2020a; 2020b; Garcés-Mascareñas and Gebhardt, 2020), on the one hand, and the involvement of civil society actors opposing migration on the other. Civil society can influence the implementation of policies, as well as the production of borders and the discussions, struggles, and resistance practices against such borders. In this regard, nor should the role of refugees themselves be neglected, because migrant social movements also try to influence policies (Dajani, 2020; Oikonomakis, 2018; Parsanoglou, 2020).

We therefore consider the concept of "battleground" (Ambrosini 2018; 2021; Campomori and Ambrosini, 2020) to be a useful means to comprehend the contentious aspects of the MLG of migration. A battleground perspective highlights the dynamism within the MLG framework whereby several actors and subjects interact - in a cooperative and/or conflictual manner - for the management of migration and asylum processes at different levels (Ambrosini, 2020).This becomes apparent when local authorities oppose national government policies by promoting welfare services, for instance. Or when civil society actors support local authority stances while movements against migrants mobilize and denounce them.

At the international level, this concept may be applied when NGO boats rescue migrants adrift in the Mediterranean Sea despite the opposition of political or judicial powers. But it may also be applied to transnational municipal networks 
of "cities of refuge" aimed at influencing national policies; or to occasions when activists or volunteers help asylum seekers and refugees to cross national borders, thus acting against police controls. Therefore, the concept of "battleground" helps us to understand why the outcomes of asylum governance are often different from what has been planned or announced by central governments. Similarly, it helps us to grasp what happens within fractured political and social landscapes, like that of Europe, where several actors of different nature (public or private) and role (citizens, volunteers, activists, social workers, researchers), operating at different levels (local, national, international), are engaged in redefining European borders at a time of change and conflict (Fontanari and Borri, 2017: 33). Future research should therefore more closely investigate the actual dynamics of interaction among actors of different kinds and at different scales of government; as well as how these dynamics can shape migration governance. This will show whether and how policies can be challenged from below.

Although this consideration emerges from a literature review that largely focuses on the reception of refugees and asylum seekers, we argue that such dynamics may also be present in the post-reception period. This concerns issues regarding the integration of refugees into local communities, as well as of refugees whose applications for asylum have been rejected, so that they lapse into irregularity. The access of both refugees and (irregular) migrants to services, housing, labour market and welfare should be studied through the lens of conflictual interaction among different actors.

\section{References}

Agier Michel (2014) Parcours dans un paysage flottant de frontières, Revue Européenne des Migrations Internationales, 30 (2), pp. 13-23.

Agier Michel, Bouagga Yasmine, Galisson Maël, Hanappe Cyrille, Pette Mathilde et Wannesson Philippe (2018) La jungle de Calais, Paris, PUF.

Agustín Óscar Garcia and Jorgensen Martin Bak (2019) Solidarity and the "refugee crisis" in Europe, London, Palgrave Macmillan.

Alcantara Christopher, Brosheck Jörg and Nells Jen (2016) Rethinking multilevel governance as an instance of multilevel politics: a conceptual strategy, Territory, Politics, Governance, 4 (1), pp. 33-51.

Alexander Michael (2007) Cities and Labour Immigration. Comparing Policy Responses, Aldershot, Asghate.

Ambrosini Maurizio (2021)The battleground of asylum and immigration policies: a conceptual inquiry, Ethnic and Racial Studies, 44 (3), pp. 374-395.

Ambrosini Maurizio (2019) The Imaginary Invasion: How the Discourse on the "Refugee Crisis" Has Impacted Italian Politics and Society, in Andrea Rea, Marco Martiniello, Alessandro Mazzola and Bart Meuleman Eds., The Refugee Reception Crisis in Europe. Polarized Opinions and Mobilizations, Bruxelles, Éditions de I'Université de Bruxelles, pp. 145-170.

Ambrosini Maurizio (2018) Irregular Immigration in Southern Europe. Actors, Dynamics and Governance, London, Palgrave Macmillan. 
Ambrosini Maurizio (2017) Why irregular migrants arrive and remain: the role of intermediaries, Journal of Ethnic and Migration Studies, 43 (11), pp. 1813-1830.

Ambrosini Maurizio (2015) NGOs and health services for irregular immigrants in Italy: when the protection of human rights challenges the laws, Journal of Immigrant \& Refugee Studies, 13 (2), pp. 116-13.

Ambrosini Maurizio (2013) Immigration in Italy: Between Economic Acceptance and Political Rejection, Journal of International Migration and Integration, 14 (1), pp. 175-194.

Ambrosini Maurizio, Cinalli Manlio and Jacobson David (Eds.) (2020) Cities of Exclusion: Are Local Authorities Refusing Refusing Asylum Seekers?, London, Palgrave Macmillan.

Anderson Bridget (2012) What does "The Migrant" tell us about the (Good) Citizen?, COMPAS Working Paper, No. 12-94, Oxford, Oxford University.

Atac Ilker, Rygiel Kim and Stierl Maurice (2016) Introduction: The Contentious Politics of Refugee and Migrant Protest and Solidarity Movements: Remaking Citizenship from the Margins, Citizenship Studies, 20 (5), pp. 527-544.

Basaran Tugba (2008) Security, law, borders: Spaces of exclusion, International Political Sociology, 2 (4), pp. 339-354.

Bauder Harald (2017) Sanctuary Cities: Policies and Practices in International Perspective, International Migration, 55 (2), pp. 174-187.

Bazurli Raffaele (2019) Local Governments and Social Movements in the "Refugee Crisis": Milan and Barcelona as "Cities of Welcome", South European Society and Politics, 24 (3), pp. 343-370.

Belloni Milena (2016) Learning How to Squat : Cooperation and Conflict between Refugees and Natives in Rome, Journal of Refugee Studies, 29 (4), pp. 506-527.

Boersma Kees, Kraiukhina Anastasiia, Larruina Robert, Lehota Zsofia and Nury Elham Omar (2019) A port in a storm: Spontaneous volunteering and grassroots movements in Amsterdam. A resilient approach to the (European) refugee crisis, Social Policy \& Administration, 53 (5), pp. 728-742.

Bolzoni Magda, Gargiulo Enrico and Manocchi Michele (2015) The social consequences of the denied access to housing for refugees in urban settings: the case ofTurin, Italy, International Journal of Housing Policy, 15 (4), pp. 400-417.

Bonizzoni Paola (2020) The Border(s) Within: Formal and Informal Processes of Status Production, Negotiation and Contestation in a Migratory Context, in Maurizio Ambrosini, Manlio Cinalli and David Jacobson Eds., Cities of Exclusion: Are Local Authorities Refusing Refusing Asylum Seekers?, London, Palgrave Macmillan, pp. 217-236.

Bonizzoni Paola (2019). Substituting, complementing, denouncing: Exploring avenues and dilemmas of volunteers' engagement in the emerging Italian refugees' reception system, No. paper presented at Social Citizenship, Migration and Conflict - Equality and opportunity in European welfare states, Stockholm, September 5-7.

Bozorgmehr Kayvan, Samuilova Mariya, Petrova-Benedict Roumyana, Girardi Enrico, Piselli Pierluca and Kentikelenis Alexander (2019) Infectious disease health services for refugees and asylum seekers during a time of crisis: A scoping study of six European Union countries, Health Policy, 123 (9), pp. 882-887. 
Broadhead Jacqueline (2020) Building inclusive cities: reflections from a knowledge exchange on the inclusion of newcomers by UK local authorities, Comparative Migration Studies, 8 (14), pp. 1-17.

Campesi Giuseppe (2014) Immigrant detention and the double logic of securitization in Italy, in Michela Ceccorulli and Nicola Labanca Ed., The EU, migration and the politics of administrative detention, pp. 161-182.

Campomori Francesca and Ambrosini Maurizio (2020) Beyond multilevel governance: the implementation of asylum seekers' reception in Italy as a battleground, Comparative Migration Studies, 8 (22), pp. 1-22.

Campomori Francesca and Caponio Tiziana (2017) Immigrant integration policymaking in Italy: regional policies in a multi-level governance perspective, International Review of Administrative Sciences, 83 (2), pp. 303-321.

Caponio Tiziana (2018) Immigrant Integration beyond National Policies? Italian Cities' Participation in European City Networks, Journal of Ethnic and Migration Studies, 44 (11-12), pp. 2053-2069.

Caponio Tiziana and Jones-Correa Michael (2018) Theorising migration policy in multilevel states: the multilevel governance perspective, Journal of Ethnic and Migration Studies, 44 (12), pp. 1995-2010.

Cappiali Teresa M. (2016) Activism of immigrants in vulnerable conditions and radical-left allies: a case study of Italy's Struggle of the Crane, Journal of Ethnic and Migration Studies, 42 (15), pp. 2508-2527.

Castelli Gattinara Pietro (2017) Mobilizing against "the invasion": Far right protest and the "refugee crisis" in Italy, Mondi Migranti, 3, pp. 75-95.

Cassarino Jean-Pierre (2016) Réadmisșion des migrants : les faux-semblants des partenariats euro-africains, Politique Étrangère, 16 (1), pp. 25-37.

Chacko Elizabeth and Price Marie (2020) (Un)settled sojourners in cities: the scalar and temporal dimensions of migrant precarity, Journal of Ethnic and Migration Studies, pp. 1-18.

Chtouris Sotiris and Miller De Mond S. (2017) Refugee Flows and Volunteers in the Current Humanitarian Crisis in Greece, Journal of Applied Security Research, $12(1)$, pp. 61-77.

Chibrac Lucienne (2004) Assistance et secours auprès des étrangers. Le service social d'aide aux émigrants (SSAE) 1920-1945, PhDThesis, Université Lumière Lyon 2.

Chimienti Milena (2011) Mobilization of irregular migrants in Europe: A comparative analysis, Ethnic and Racial Studies, 34 (8), pp. 1338-1356.

Christodoulou Yannis, Papada Evie, Papoutsi Anna and Vradis Antonis (2016) Crisis or Zemblanity? Viewing the "Migration Crisis" through a Greek Lens, Mediterranean Politics, 21 (2), pp. 321-325.

Dajani Deena (2020) Refuge under austerity: the UK's refugee settlement schemes and the multiplying practices of bordering, Ethnic and Racial Studies, 44 (1), pp. 1-19.

Della Porta Donatella (Ed.) (2018) Solidarity Mobilizations in the "Refugee Crisis". Contentious Moves, Cham, Palgrave.

Denaro Chiara (2016) Agency, resistance and (forced) mobilities. The case of Syrian refugees in transit through Italy, REMHU: Revista Interdisciplinar da Mobilidade Humana, 24 (47), pp. 77-96. 
Ekman Mattias (2018) Anti-refugee Mobilization in Social Media: The Case of Soldiers of Odin, Social Media and Society, 4 (1), pp. 1-11.

Ellermann Antje (2006) Street-level democracy: How immigration bureaucrats manage public opposition, West European Politics, 29 (2), pp. 293-309.

Faist Thomas (2013) The mobility turn: A new paradigm for the social sciences?, Ethnic and Racial Studies, 36 (11), pp. 1637-1646.

Feischmidt Margit (2020) Deployed fears and suspended solidarity along the migratory route in Europe, Citizenship Studies, 24 (4), pp. 441-456.

Feischmidt Margit and Zakariás Ildikó (2020) How Migration Experience Affects the Acceptance and Active Support of Refugees? Philanthropy and Paid Work of Hungarian Migrants in the German Immigrant Service, Journal of Immigrant and Refugee Studies, 18 (4), pp. 481-497.

Fleischmann Larissa (2017) The Politics of Helping Refugees Emerging Meanings of Political Action around the German Summer of Welcome, Mondi Migranti, 3, pp. 53-73.

Fleischmann Larissa and Steinhilper Elias (2017) The myth of apolitical volunteering for refugees: German welcome culture and a new dispositif of helping, Social Inclusion, 5 (3), pp. 17-27.

Fontanari Elena (2018) Lives in Transit: An Ethnographic Study of Refugees' Subjectivity across European Borders, London, Routledge.

Fontanari Elena and Ambrosini Maurizio (2018) Into the Interstices: Everyday Practices of Refugees and Their Supporters in Europe's Migration "Crisis", Sociology, 52 (3), pp. 587-603.

Fontanari Elena and Borri Giulia (2017) Introduction. Civil society on the edge: actions in support and against refugees in Italy and Germany. Mondi Migranti, 11 (3), pp. 23-51.

Fouskas Theodoros (2019) Unravelling Solidarity and Hostility: Mobilizations Concerning Migrants, Asylum Seekers and Refugees in Anti-Migrant Times in Greece, in Andrea Rea, Marco Martiniello, Alessandro Mazzola and Bart Meuleman Eds., The Refugee Reception Crisis in Europe. Polarized Opinions and Mobilizations, Bruxelles, Éditions de I'Université de Bruxelles, pp. 121-144.

Frazzetta Federica and Piazza Gianni (2020) The protests of migrants in Sicily: Why are there few and only single-issue, Geopolitics, pp. 1-24.

Garcés-Mascareñas Blanca and Gebhardt Dirk (2020) Barcelona: municipalist policy entrepreneurship in a centralist refugee reception system, Comparative Migration Studies, 8 (1), pp. 1-15.

Gargiulo Enrico (2017) The limits of local citizenship: administrative borders within the Italian municipalities, Citizenship Studies, 21 (3), pp. 327-343.

Gargiulo Enrico (2012) L'“emergenza" dell'esclusione: il controllo locale dell'immigrazione nel contesto italiano, La Rivista delle Politiche Sociali, 1, pp. 89-116.

Garkisch Michael, Heidingsfelder Jens and Beckmann Markus (2017)Third Sector Organizations and Migration: A Systematic Literature Review on the Contribution of Third Sector Organizations in View of Flight, Migration and Refugee Crises, Voluntas, 28 (5), pp. 1839-1880.

Genova Nicholas (De) (2013) Spectacles of migrant "illegality": the scene of exclusion, the obscene of inclusion, Ethnic and Racial Studies, 36 (7), pp. 1180-1198. 
Gilbert Liette (2009) Immigration as local politics: Re-bordering immigration and multiculturalism through deterrence and incapacitation, International Journal of Urban and Regional Research, 33 (1), pp. 26-42.

Giliberti Luca (2017) La criminalizzazione della solidarietà ai migranti in Val Roja: note dal campo, Mondi Migrantii, 3, pp. 161-181.

Giliberti Luca and Queirolo Palmas Luca (2020) Solidarities in Transit on the French-Italian Border: Ethnographic Accounts from Ventimiglia and the Roya Valley, in Maurizio Ambrosini, Manlio Cinalli and David Jacobson Eds., Cities of Exclusion: Are Local Authorities Refusing Refusing Asylum Seekers?, London, Palgrave Macmillan, pp. 109-140.

Giraudon Virginie (2000) European integration and migration policy: Vertical policy-making as venue shopping, Journal of Common Market Studies, 38 (2), pp. 251-271.

Gjergji Iside (2016) La cittadinanza degli stranieri: una trama scaturita dai "laboratori segreti" della pubblica amministrazione, in Daniele Andreozzi and Sara Tonolo Eds., La cittadinanza molteplice. Ipotesi e comparazioni, Trieste, Università di Trieste, pp. 25-38.

Glick Schiller Nina and Çağlar Ayse (2009) Towards a Comparative Theory of Locality in Migration Studies: Migrant Incorporation and City Scale, Journal of Ethnic and Migration Studies, 35 (2), pp. 177-202.

Glick Schiller Nina and Salazar Noel B. (2013) Regimes of Mobility Across the Globe, Journal of Ethnic and Migration Studies, 39 (2), pp. 183-200.

Glorius Birgit and Doomernik Jeroen (2020) Geographies of Asylum in Europe and the Role of European Localities, IMISCOE Reserch Series, Cham, Springer.

Grazioli Margherita (2017) From citizens to citadins? Rethinking right to the city inside housing squats in Rome, Italy, Citizenship Studies, 21 (4), pp. 393-408.

Green Sarah (2013) Borders and the Relocation of Europe, Annual Review of Anthropology, 42 (1), pp. 345-361.

Haas Hein (de), Natter Katharina and Vezzoli Simona (2016) Growing Restrictiveness or Changing Selection? The Nature and Evolution of Migration Policies, International Migration Review, 52 (2), pp. 324-367.

Hajer Minke H. J. and Maurizio Ambrosini (2020) Who help irregular migrants? Supporters of irregular migrants in Amsterdam (the Netherlands) andTurin (Italy), REMHU: Revista Interdisciplinar da Mobilidade Humana, 28 (59), pp. 99-216.

Hamann Ulrike and Karakayali Serhat. (2016) Practicing willkommenskultur: Migration and solidarity in Germany, Intersections, 2 (4), pp. 70-86.

Haselbacher Miriam (2019) Solidarity as a field of political contention: Insights from local reception realities, Social Inclusion, 7 (2), pp. 74-84.

Haselbacher Miriam and Rosenberger Sieglinde (2018) Protest against the reception of asylum seekers in Austria, in Rosenberger Sieglinde, Verena Stern and Nina Merhaut Eds., Protest movements in asylum and deportation, IMISCOE research series, Cham, Springer, pp. 247-269.

Heelsum Anja (van) (2017) Aspirations and frustrations: experiences of recent refugees in the Netherlands, Ethnic and Racial Studies, 40 (13), pp. 2137-2150. 
Hess Sabine, Kasparek Bernd, Kron Stefanie, Rodatz Mathias, Schwertl Maria and Sontowski Simon (2017) Der lange sommer der migration, Berlin and Hamburg, Assoziation A.

Hinger Sophie and Schäfer Philipp (2019) Making a difference. The accommodation of refugees in Leipzig and Osnabruck, Erdkunde, 73 (1), pp. 63-67.

Hinger Sophie, Schäfer Philipp and Pott Andreas (2016) The Local production of Asylum, Journal of Refugee Studies, 29 (4), pp. 440-463.

Hintjens Helen and Pouri Ahmed (2014) Toward Cities of Safety and Sanctuary, Peace Review, 26 (2), pp. 218-224.

Hoppe-Seyler Annika (2020) Arenas of Volunteering: Experiences, Practices and Conflicts of Voluntary Refugee Relief, in Birgit Glorius and Jeroen Doomernik Eds., Geographies of Asylum in Europe and the Role of European Localities, IMISCOE, Springer Open, pp. 225-244.

Ikizoglu Erensu Asli (2016) Notes from a refugee protest: ambivalences of resisting and desiring citizenship, Citizenship Studies, 20 (5), pp. 664-677.

Irgil Ezgi (2016) Multi-Level Governance As an Alternative: the Municipality of Barcelona and the Ciutat Refugi Plan, Glocalism: Journal of Culture, Politics and Innovation, 3 (September), pp. 1-21.

Isin Engin F. and Turner Bryan S. (2002) Handbook of Citizenship Studies, Thousand Oaks, SAGE Publications Ltd.

Jong Sara (de) and Ataç Ilker (2017) Demand and deliver: Refugee support organisations in Austria, Social Inclusion, 5 (3), pp. 28-37.

Karakayali Serhat and Kleist Olaf J. (2016) Volunteers and asylum seekers, Forced Migration Review, 51, p. 65.

Kasparek Bernd (2016) Complementing Schengen: The Dublin System and the European Border and Migration Regime, Migration Policy and Practice, pp. 59-78.

Khosravi Shahram (2010) "Illegal" traveller: An autoethnography of borders, Basingstoke, Palgrave Macmillan.

Koca Burcu Togral (2019) Local bordering practices, refugees, and civil society: The case of Berlin, Geographical Review, 109 (4), pp. 544-561.

Koca Burcu Togral (2016) New Social Movements: "Refugees Welcome UK", European Scientific Journal, 12 (2), pp. 96-108.

Kolossov Vladimir and Scott James (2013) Selected conceptual issues in border studies, BELGEO, 1.

Kopytowska Monika, Grabowski Lukasz and Wozniak Julita (2017) Mobilizing against the Other Cyberhate. Refugee crisis and proximization, in Monika Kopytowska Ed., Contemporary discourses of hate and radicalism across space and genres, Amsterdam, John Benjamins Publishing Company, pp. 57-97.

Kos Sanne, Maussen Marcel and Doomernik Jeroen (2016) Policies of exclusion and practices of inclusion: How municipal governments negotiate asylum policies in The Netherlands, Territory, Politics, Governance, 4 (3), pp. 354-371.

Lafleur Jean-Michel and Mescoli Elsa (2018) Creating Undocumented EU Migrants through Welfare: A Conceptualization of Undeserving and Precarious Citizenship, Sociology, 52 (3), pp. 480-496. 
Larruina Robert, Boersma Kees and Ponzoni Elena (2019) Responding to the Dutch asylum crisis: Implications for collaborative work between civil society and governmental organizations, Social Inclusion, 7 (2), pp. 53-63.

Lebuhn Henrik (2013) Local border practices and urban citizenship in Europe, City, 17 (1), pp. 37-51.

Lipsky Michael (1980) Street-Level Bureaucracy: Dilemma's of the Individual in Public Services, New York, Russell Sage Foundation.

Mainwaring Cetta (2016) Migrant agency: Negotiating borders and migration controls, Migration Studies, 4 (3), pp. 289-308.

Malkki Liisa (1996) Speechless emissaries: Refugees, humanitarianism, and dehistoricization, Cultural Anthropology, 11 (3), pp. 377-404.

Marchetti Chiara (2020) Cities of Exclusion: Are Local Authorities Refusing Asylum Seekers?, in Maurizio Ambrosini, Manlio Cinalli and David Jacobson Eds., Cities of Exclusion: Are Local Authorities Refusing Refusing Asylum Seekers?, London, Palgrave Macmillan, pp. 237-263.

Marciniak Katarzyna and Tyler Imogen (2014) Immigrant protest: Politics, aesthetics, and everyday dissents, Yogyakarta, UNY Press.

Marino Stefania, Roosblad Judith and Penninx Rinus (Eds.) (2017) Trade unions and migrant workers. New Contexts and Challenges in Europe, Cheltenham, Edward Elgar Publishing.

Marrow Helen B. (2012) The power of local autonomy: expanding health care to unauthorized immigrants in San Francisco, Ethnic and Racial Studies, 35 (1), pp. 72-87.

Marzorati Roberta, Semprebon Michaela and Bonizzoni Paola (2017) Between Substitution, Complementarity and Delegation: the role of the Third Sector in Migration Governance in Small-sized Towns in Italy, Paper presented at the IMISCOE Conference 2017 "Migration, Diversity and the City", June 28-30, Rotterdam, The Netherlands.

Mayer Margit (2018) Cities as sites of refuge and resistance, European Urban and Regional Studies, 25 (3), pp. 232-249.

Mezzadra Sandro (2020) Abolitionist vistas of the human. Border struggles, migration and freedom of movement, Citizenship Studies, 24 (4), pp. 424-440.

Mezzadra Sandro and Neilson Brett (2013) Border as Method, or, the Multiplication of Labor, Durham, Duke University Press.

Monforte Pierre and Dufour Pascale (2011) Mobilizing in borderline citizenship regimes: A comparative analysis of undocumented migrants' collective actions, Politics and Society, 39 (2), pp. 203-232.

Morris Lydia (2003) Managing Migration: Civic Stratification and Migrants Rights, London, Routledge.

Narkowicz Kasia (2018) "Refugees Not Welcome Here": State, Church and Civil Society Responses to the Refugee Crisis in Poland, International Journal of Politics, Culture and Society, 31 (4), pp. 357-373.

Nicholls Walter J. (2013a) Fragmenting citizenship: dynamics of cooperation and conflict in France's immigrant rights movement, Ethnic \& Racial Studies, 36 (4), pp. 611-631. 
Nicholls Walter J. (2013b) Making undocumented immigrants into a legitimate political subject: Theoretical observations from the United States and France, Theory, Culture \& Society, 30 (3), pp. 82-107.

Nordling Vanna, Sager Maja and Söderman Emma (2017) From citizenship to mobile commons: reflections on the local struggles of undocumented migrants in the city of Malmö, Sweden, Citizenship Studies, 21 (6), pp. 710-726.

Nyers Peter and Rygiel Kim (2012) Citizenship, migrant activism and the politics of movement, London, Routledge.

Odmalm Pontus (2004) Civil society, migrant organisations and political parties: Theoretical linkages and applications to the Swedish context, Journal of Ethnic and Migration Studies, 30 (3), pp. 471-489.

Oikonomakis Leonidas (2018) Solidarity in Transition: The case of Greece, in Donatella della Porta Ed., Solidarity Mobilizations in the "Refugee Crisis" Contentious Moves, London, Palgrave Macmillan, pp. 65-98.

Ong Aihwa (2006) Neoliberalism as Exception: Mutations in Citizenship and Sovereignty, Durham, NC, Duke University Press.

Oomen Barbara (2020a) Cities of Refuge: Rights, Culture and the Creation of Cosmopolitan Cityzenship, in Rosemarie Buikema, Antoine Buyse and Antonius C. G. M. Robben Eds., Cultures, Citizenship and Human Rights, London and New York, Routdledge, pp. 121-136.

Oomen Barbara (2020b) Decoupling and Teaming up: The Rise and Proliferation of Transnational Municipal Networks in the Field of Migration, International Migration Review, 54 (3), pp. 913-939.

Oomen Barbara and Leenders Emma (2020) Symbolic Laws, Street-Level Actors: Everyday Bordering in Dutch Participation Declaration Workshops, in Maurizio Ambrosini, Manlio Cinalli and David Jacobson Eds., Cities of Exclusion: Are Local Authorities Refusing Refusing Asylum Seekers?, London, Palgrave Macmillan, pp. 265-294.

Panizzon Marion and Riemsdijk Micheline (van) (2019) Introduction to Special issue: "migration governance in an era of large movements: a multi-level approach", Journal of Ethnic and Migration Studies, 45 (8), pp. 1225-1241.

Parsanoglou Dimitris (2020) Volunteering for refugees and the repositioning of state sovereignty and civil society: the case of Greece, Citizenship Studies, 24 (4), pp. 457-473.

Pettrachin Andrea (2020) Understanding the "Refugee Crisis": An Actor, Centred Analysis of the Constitution of Asylum Governance in Italy, PhD Dissertation, The University of Sheffield, Faculty of Social Sciences Department of Politics.

Picker Giovanni and Vivaldi Elisabetta (2019) Racial Segregation: Camps for Roma and Slums in Italy, in Ismael Cortés Gómez and Markus End Eds., Dimensions of Antigypsyism in Europe. Brussels, European Network Against Racism (ENAR), pp. 180-197.

Picozza Fiorenza (2017) Dublin on the move, Movements Journal für kritische Migrations- und Grenzregimeforschung, 3 (1), pp. 71-88.

Ponzo Irene and Pogliano Andrea (2019) Asilo e crisi urbane: dinamiche di narrative-making tra media e policy network locali, Mondi Migranti, 1, pp. 119-141. 
Price Jonathan and Spencer Sarah (2014) City-Level Responses to Migrant Families with Restricted Access to Welfare Benefits, Oxford, COMPAS, University of Oxford.

Pries Ludger (2018) Refugees, civil society and the state: European experiences and global challenges, Cheltenham, Edward Elgar Publishing.

Putnam Robert D. (1993) Making democracy work: Civic traditions in modern Italy, Princeton, Princeton University press.

Rahola Federico (2010)The space of camps, in Alessandro Dal Lago and Salvatore Palidda Eds., Conflict, Security and the Reshaping of Society. The Civilization of war, London, Routledge, pp. 185-199.

Raimondi Valeria (2019) For "common struggles of migrants and locals". Migrant activism and squatting in Athens, Citizenship Studies, 23 (6), pp. 559-576.

Rajaram Prem Kumar (2002) Humanitarianism and representations of the refugee, Journal of Refugee Studies, 15 (3), pp. 247-264.

Ridgley Jennifer (2008) Cities of refuge: Immigration enforcement, police, and the insurgent genealogies of citizenship in US sanctuary cities, Urban Geography, 29 (1), pp. 53-77.

Rigo Enrica (2011) Citizens despite borders: challenges to the territorial order of Europe, in Vicki Squire Ed., The Contested Politics of Mobility, London, Routledge, pp. 199-215.

Rucht Dieter (2018) Mobilization against refugees and asylum seekers in Germany: A social movement perspective, in Sieglinde Rosenberger, Verena Stern and Nina Merhaut Eds., Protest movements in asylum and deportation, IMISCOE, Cham, Springer, pp. 225-245

Sandri Elisa (2018) "Volunteer humanitarianism": Volunteers and humanitarian aid in the jungle refugee camp of Calais, Journal of Ethnic and Migration Studies, 44 (1), pp. 65-80.

Schiller Maria, Martínez-Ariño Julia and Bolíbar Mireia (2020) A relational approach to local immigrant policy-making: collaboration with immigrant advocacy bodies in French and German cities, Ethnic and Racial Studies, 43 (11), pp. 2041-2061.

Schmoll Camille, Thiollet Hélène, Wihtol de Wenden Cartherine (Eds.) (2015) Migrations en Méditerranée, Paris, CNRS éditions.

Scholten Peter (2015) Between National Models and Multi-Level Decoupling:The Pursuit of Multi-Level Governance in Dutch and UK Policies Towards Migrant Incorporation, Journal of International Migration and Integration, 17 (4), pp. 1-22.

Scholten Peter, Engbersen Godfried, van Ostaijen Mark and Snel Erik (2018) Multilevel governance from below. How Dutch cities respond to intra-EU mobility, Journal of Ethnic and Migration Studies, 44 (11-12), pp. 2011-2033.

Schweitzer Reinhard (2019) Health Care Versus Border Care: Justification and Hypocrisy in the Multilevel Negotiation of Irregular Migrants' Access to Fundamental Rights and Services, Journal of Immigrant and Refugee Studies, $17(1)$, pp. 61-76.

Schwiertz Helge and Schwenken Helen (2020) Introduction: inclusive solidarity and citizenship along migratory routes in Europe and the Americas, Citizenship Studies, 24 (4), pp. 405-423. 
Scott James C. (1985) Weapons of the weak, New Haven, Yale University Press.

Semelin Jacques (2018) La Survie Des Juifs En France, 1940-1944, Paris, CNRS éditions.

Semprebon Michela (2011) Phone centres and the struggle for public space in Italy: between revanchist policies and practices of resistance, Journal of Urbanism: International Research on Placemaking and Urban Sustainability, 4 (3), pp. 223-237.

Semprebon Michela and Pelacani Gracy (2020) Dispersal and Reception in Northern Italy: Comparing Systems Along the Brenner Route, in Birgit Glorius and Jeroen Doomernik, Geographies of Asylum in Europe and the Role of European Localities, IMISCOE, Springer Open, pp. 15-43

Simsa Ruth (2017) Leaving Emergency Management in the Refugee Crisis to Civil Society? The Case of Austria, Journal of Applied Security Research, 12 (1), pp. 78-95.

Sinatti Giulia (2019) Humanitarianism as Politics: Civil Support Initiatives for Migrants in Milan's Hub, Social Inclusion, 7 (2), pp. 1-10.

Spencer Sarah (2018) Multi-level governance of an intractable policy problem: migrants with irregular status in Europe, Journal of Ethnic and Migration Studies, 44 (12), pp. 2034-2052.

Squire Vicki and Darling Jonathan (2013) The "minor" politics of rightful presence: Justice and relationality in City of Sanctuary, International Political Sociology, 7 (1), pp. 59-74.

Stålsett Sturla J. (2018) Fearing the faith of others? Government, religion, and integration in Norway, in Ulrich Schmiedel and Graeme Smith Eds., Religion in the European refugee crisis, Cham, Springer, pp. 105-120.

Tazzioli Martina (2018) Containment through mobility: migrants' spatial disobediences and the reshaping of control through the hotspot system, Journal of Ethnic and Migration Studies, 44 (16), pp. 2764-2779.

Tazzioli Martina and Garelli Glenda (2018) Containment beyond detention: The hotspot system and disrupted migration movements across Europe, Environment and Planning D: Society and Space, February, pp. 1-19.

Ticktin Miriam (2014) Transnational Humanitarianism, Annual Review of Anthropology, 43, pp. 273-289.

Torpey John (2000) The Invention of the Passport. Surveillance, Citizenship and the State, Cambridge, Cambridge University Press.

Tsavdaroglou Charalampos, Giannopoulou Chrisa, Petropoulou Chryssanthi and Pistikos Ilias (2019) Acts for refugees' right to the city and commoning practices of care-tizenship in Athens, Mytilene and Thessaloniki, Social Inclusion, 7 (4), pp. 119-130.

Tuastad Dag (2017) "State of exception" or "state in exile"? The fallacy of appropriating Agamben on Palestinian refugee camps", Third World Quarterly, 38 (9), pp. 2159-2170.

Vandevoordt Robin (2019a) Eroding rights, crafting solidarity? Shifting dynamics in the state-civil society nexus in Flanders and Brussels, Social Inclusion, 7 (2), pp. 106-117. 
Vandevoordt Robin (2019b) Subversive humanitarianism: Rethinking refugee solidarity through grass-roots initiatives, Refugee Survey Quarterly, 38 (3), pp. 245-265.

Vandevoordt Robin and Verschraegen Gert (2019) The European refugee controversy: Civil solidarity, cultural imaginaries and political change, Social Inclusion, $7(2)$, pp. $48-52$.

Walters William (2015) Reflections on Migration and Governmentality, Movements. Journal for Critical Migration and Border Regime Studies, 1 (1).

Weissensteiner Monika (2015) Da Lampedusa al Brennero. Per una cultura dell'accoglienza, Quaderno della Fondazione Alexander Langer Stiftung, 3, pp. 38-39.

Youkhana Eva and Sutter Ove (2017) Perspectives on the European Border Regime: Mobilization, Contestation and the Role of Civil Society, Social Inclusion, 5 (3), pp. 1-6.

Zamponi Lorenzo (2017) Practices of Solidarity: Direct Social Action, Politicisation and Refugee Solidarity Activism in Italy, Mondi Migranti, 3, pp. 97-117.

Zapata-Barrero Ricard, Caponio Tiziana and Scholten Peter (2017) Theorizing the "local turn" in a multi-level governance framework of analysis: a case study in immigrant policies, International Review of Administrative Sciences, 83 (2), pp. 241-246.

Zimmermann Inga, Rosenow-Williams Kerstin, Behmer-Prinz Katharina and Bergedieck Alina (2020) Refugee Protection Standards in Transition: Studying German NGOs and Public Administrations, Refugee Survey Quarterly, 39 (1), pp. 76-99. 


\section{Iraklis Dimitriadis, Minke H. J. Hajer, Elena Fontanari and Maurizio Ambrosini}

\section{Local "Battlegrounds": Relocating Multi-Level and Multi-Actor Governance of Immigration}

The multi-level governance (MLG) approach is widely used to understand the complex processes of immigration policymaking. In this literature review, we consider both (i) the vertical dimension of MLG: the local, regional, national, European, or even global level; and (ii) the horizontal dimension of MLG: the relations between public and non-public actors. While focusing on the local level, this review identifies a trend regarding, on the one hand, local processes of bordering, and local policies of inclusion on the other. Furthermore, the article reviews how civil society has responded to the arrival of refugees. It identifies how this literature pays insufficient attention to dimensions of conflict and, more specifically, to how local borders can be challenged. Moreover, it shows a lack of attention to anti-migrant responses, and to the interaction between migrants and civil society regarding immigration governance. Concluding, the paper argues for the adoption of a "battleground" perspective as a more dynamic basis for the MLG approach.

\section{La politique migratoire comme "champ de bataille " (Battleground). Relocaliser la gouvernance multi-niveaux et multi-acteurs de I'immigration}

L'approche théorique de la gouvernance multi-niveaux (GMN) est largement utilisée pour comprendre les processus complexes d'élaboration des politiques migratoires. Dans cet article, nous proposons, sous la forme d'un état de l'art, une analyse de la dimension verticale (niveau local, régional, national, européen ou mondial) et horizontale (relations entre acteurs publics et non publics) de la GMN. Centré sur le niveau local et sur les questions d'asile, cet article identifie une tendance concernant, d'une part, les processus locaux de définition des frontières, et d'autre part, les politiques locales d'inclusion. En outre, nous examinons comment la société civile a réagi face aux arrivées de réfugiés. L'article montre que la littérature sur la GMN n'a pas accordé assez d'attention à la question du conflit et à la façon dont celui-ci peut déplacer les frontières sociales au niveau local. La littérature a insuffisamment abordé les mobilisations anti-migrants et les interactions entre migrants et société civile. En conclusion, nous ajoutons que le concept de " champ de bataille " (Battlegrounds) permet une compréhension plus dynamique de la GMN. 


\section{Los "campos de batalla" locales (Battlegrounds). Reubicación de la gobernanza multinivel y multiactor de la inmigración. Revisión de la literatura}

La gobernanza multinivel (MLG por su acrónimo inglés) es un enfoque ampliamente utilizado para comprender los complejos procesos de formulación de políticas públicas en torno al tema de la inmigración. Esta revisión de la literatura analiza tanto la dimensión vertical de la MLG: el nivel local, regional, nacional, europeo o incluso global; como la dimensión horizontal de la misma: las relaciones entre actores públicos y no públicos. Centrándose en el nivel local y particularmente en el tema del asilo, esta revisión bibliográfica identifica una tendencia con respecto a los procesos locales de frontera por un lado, y las políticas locales de inclusión por el otro. Las dimensiones del conflicto y el cómo se desafían las fronteras locales no se tratan exhaustivamente en este documento. Sin embargo, a este respecto revisamos cómo la sociedad civil ha respondido a la llegada de refugiados. Esta literatura no ha otorgado suficiente atención a las respuestas anti-inmigrantes, y a cómo la sociedad civil y los migrantes interactúan en relación a la gobernanza de la inmigración. Concluimos elaborando sobre la manera en la que un marco conceptual en términos de "campo de batalla" (Battlegrounds) permite aplicar una perspectiva dinámica al entendimiento de la gobernanza multinivel o MLG. 